The Open Biotechnology Journal
Bentham OPEN
CrossMark
DOI: $10.2174 / 1874070701610010342$

REVIEW ARTICLE

\title{
Antibiotic Resistant Bacteria in the Environment as Bio-Indicators of Pollution
}

\author{
James R. Paulson ${ }^{1, *}$, Ibrahim Y. Mahmoud ${ }^{2}$, Salma K. Al-Musharafi ${ }^{3}$ and Saif N. Al-Bahry ${ }^{4}$ \\ ${ }^{I}$ Department of Chemistry, University of Wisconsin-Oshkosh, Oshkosh, WI 54901, USA \\ ${ }^{2}$ Department of Biological Sciences and Chemistry, University of Nizwa, Nizwa, Sultanate of Oman \\ ${ }^{3}$ Department of Applied Biotechnology, Sur College of Applied Sciences, Sur, Sultanate of Oman \\ ${ }^{4}$ Department of Biology, College of Science, Sultan Qaboos University, Muscat, Sultanate of Oman
}

Received: March 13, 2016

Revised: May 02, 2016

Accepted: June 27, 2016

\begin{abstract}
Antibiotic resistant and multiple-antibiotic resistant bacteria (MARB) have become increasingly widespread, primarily due to overuse of antibiotics in clinical therapeutics and in growth promotion for livestock. This undermines the usefulness of the drugs and presents a serious problem for human health. Compounding the problem, resistance determinants can spread between different bacteria via transfer of genetic material, so that the digestive tracts of farm animals, for example, have become breeding grounds for MARB. Antibiotics and resistant bacteria enter the environment in both treated and untreated sewage, via wastewater streams from hospitals and pharmaceutical plants, and through agricultural runoff from feedlots and fields fertilized with manure. This has led to contamination of groundwater, lakes, rivers and coastal sea water, and high levels of MARB in wildlife which indicates pollution of these habitats. Here we propose that the level of antibiotic-resistant bacteria in wildlife, for example sea turtles and fish, could be used as a bioindicator to monitor pollution and to evaluate the success of efforts to curtail it.
\end{abstract}

Keywords: Antibiotic resistance, Bioindicators, Ocean pollution, Sea turtles, Water pollution.

\section{INTRODUCTION}

The word "antibiotic" was coined by Waksman in 1947 [1] to describe organic compounds produced by microorganisms that inhibit the growth of other microorganisms: bacteria, fungi or protozoa. However, the term is now generally used (and will be used here) to refer more specifically to anti-bacterial substances. Now, it also includes synthetic and semisynthetic compounds as well as natural products.

The era of antibiotics began with the discoveries of Salvarsan (effective against syphilis) in 1909, penicillin in 1929 and sulfa drugs in the 1930s [2]. Penicillin, first mass-produced during World War II, was the first drug to be effective against common, but very serious, infections such as Streptococcus and Staphylococcus. Many new classes of antibacterial compounds were found during the "golden age" of antibiotics from about 1950-1970 [2] and they have clearly been very important tools for fighting bacterial infections.

In addition to their use in human medicine, antibiotic compounds have been widely used in agriculture to treat plant diseases (e.g., [3, 4]), in aquaculture (e.g., [5]), and both therapeutically and prophylactically in veterinary medicine [6]. Antibiotics have also been extensively used as growth promoters in farm animals. It was discovered in the 1940s that supplementing chicken feed with tetracycline helped chickens to grow faster, and later other anti-bacterials (including many that are also used in human medicine) were found to be useful as growth promoters, especially in poultry and cattle [7]. It was reported in 2004 that $40 \%$ of the antibiotics produced in the United States were being used for growth

\footnotetext{
* Address correspondence to this author at the Department of Chemistry, University of Wisconsin-Oshkosh, Oshkosh, 800 Algoma Blvd, Oshkosh, WI 54901, USA; Tel: +1-920-424-7100; Fax: +1-920-424-2042; E-mail: paulson@uwosh.edu
} 
promotion in animals [8]. However, others have put the figure closer to $80 \%$ [9].

Unfortunately, as a result of the widespread use of antibiotics over the last 50 years, many bacteria have acquired resistance and are no longer vulnerable to the drugs. Moreover, genetic rearrangements and horizontal gene transfer between different species and strains have led to the development and proliferation of multiple-antibiotic resistant bacteria (MARB), which in some cases are resistant to nearly all currently available antibiotics. This is obviously a serious health concern, since it undermines the usefulness of the drugs [10]. It is reported that in the United States more than two million people are sickened and 23,000 die each year as a result of antibiotic-resistant infections [11].

In this report, our goal is to examine the spread of antibiotic-resistant organisms to the environment. Although this does have consequences for human health, we are not directly concerned with medical aspects here. Instead, our focus is on the potential use of MARB in monitoring pollution.

We first discuss how antibiotic resistant bacteria and MARB arise. We then document their presence in the environment and show that it is mainly due to man-made pollution sources. Putting these observations together, we suggest that the presence of MARB in the environment may be useful as a bio-indicator of pollution. MARB could, for example, be helpful in identifying the sources and gauging the geographical extent of pollution and in following the steps in its alleviation or elimination.

\section{ANTIBIOTIC RESISTANT AND MULTIPLE-ANTIBIOTIC RESISTANT BACTERIA}

Antibiotic resistance is a natural phenomenon that has existed for eons. Organisms that produce antibiotic substances have always had to be resistant to the compounds they produced themselves, and other organisms living near them, for example in the soil, also had to develop resistance to survive [7]. However, over the last 70 years, as antibiotics have been mass-produced and used more and more, resistance to both naturally occurring and synthetic antibiotics has skyrocketed. It has become increasingly common to isolate antibiotic resistant bacteria from patients, animals and the environment [11 - 18].

The expansion of antibiotic resistance depends on the presence of genetic determinants that confer resistance. Such determinants may already be present in nature or may arise naturally and inevitably as a result of chance mutations. There is a great deal of genetic variability among bacteria, and in a large population at least a few cells are likely to have some measure of resistance to a given antibiotic [19]. The presence of these resistance determinants becomes evident when a bacterial population is exposed to the drug.

Exposure to antibiotics is the most important factor contributing to the spread of antibiotic resistance [20]. In the presence of the antibiotic, resistant cells have an advantage over susceptible ones and are more likely to survive and multiply, and this leads to the vertical (clonal) spread of resistance [7]. In short, when the drugs are present resistant bacteria tend to become more prevalent by a process of Darwinian natural selection.

The extent to which bacteria are exposed to antibiotics depends on how often and in what quantities the drugs are used [21], and it is because of the excessive and imprudent use of antibiotics over the last 50 years that resistance has become so widespread. When antibiotics are used improperly in medicine, resistant strains can arise among both the pathogenic and commensal bacteria of the human body, especially when broad-spectrum antibiotics are used [22 - 24]. Resistance also develops in both the pathogens and normal bacterial flora of animals when antibiotics are used as growth promoters $[7,25,26]$. Finally, resistance can emerge and/or spread when bacteria in nature are exposed to antibiotic residues that have entered the environment. In this case, antibiotic residues resulting from human activity appear to be quantitatively much more significant than naturally occurring antibiotics produced by soil microorganisms. They can enter the environment via municipal and hospital waste streams, disposal of unused drugs, effluent from pharmaceutical plants, or runoff from feedlots and other agricultural land [27].

As mentioned above, antibiotic resistance can arise de novo as a result of chance mutations. It then spreads vertically as the resistant bacteria grow and divide. Even more important, however, is the horizontal spread of resistance. This occurs by the transfer of genetic material from one bacterium to another via transduction, conjugation or transformation $[28,29]$. Genomic sequence data from many bacteria demonstrate that horizontal transfer is not uncommon in nature [29].

Horizontal transfer is significant for two reasons. First, it is well documented that it allows antibiotic resistance determinants to spread from one species of bacteria to another [30 - 32]. For example, there is good evidence for horizontal transfer of resistance genes between bacteria that cause infections in animals and those that cause infection in 
humans [33]. Second, resistance determinants for multiple antibiotics can potentially be transmitted at the same time.

Plasmids are the main vehicles for the spread of antibiotic resistance genes in bacterial populations [34]. These are small circular DNA molecules, ranging in size from a few thousand to tens of thousands of basepairs. They replicate independently of the bacterial chromosome and can be transferred from one bacterium to another.

Plasmids that carry antibiotic resistance determinants (called R-plasmids) have become very common and are a serious concern. Even R-plasmids carried by nonpathogenic bacteria are important because they can potentially be transmitted to pathogens [35]. Moreover, R-plasmids that confer resistance to multiple antibiotics have emerged, giving rise to multiple-antibiotic resistant bacteria (MARB) which have become widespread. Sometimes ten or more resistance genes may be located on the same plasmid [36]. It is thought that much of the recombination and rearrangement of antibiotic resistance genes may involve transposable elements (transposons) [34, 37]. In any case, the existence of MARB has the consequence that resistance to several drugs can be transferred to other bacteria at the same time, but only one of those drugs needs to be present in order to select for the presence of the R-plasmid [19, 25].

\section{BREEDING GROUNDS FOR MARB}

Bacterial strains showing resistance to multiple antimicrobial drugs are clearly a public health concern, and so it is important to understand how and where they emerge. They can arise in humans, animals, or the environment, usually as a result of excessive, inappropriate and indiscriminate usage of antibiotics [22].

Horizontal (and subsequent vertical) spread of antibiotic resistance and multiple-antibiotic resistance occurs most readily when resistance determinants are present, when the population density of bacteria is very high, and when antibiotics are present. Such conditions are present in the digestive tracts of humans and domesticated animals that have been exposed to antibiotics and consequently these are ideal locations for efficient transmission of resistance genes among pathogenic and non-pathogenic (commensal) bacteria [38]. Thus, the intestines of humans and animals are important breeding grounds for MARB and comprise the largest reservoirs of resistance genes [20].

The digestive tracts of food-producing animals are particularly important, since enormous amounts of different drugs have been used rather indiscriminately for growth promotion, as well as for prevention and treatment purposes [9, 22]. These practices have led to an increased frequency of MARB among the enteric bacteria in farm animals [25, 39] and in their fecal flora [26]. For example, E. coli is a major reservoir for resistance genes and therefore a useful indicator of resistance in bacterial communities [40]. In one study in Oman in 1986, about a third of E. coli isolates from chickens were resistant to at least two antibiotics, but a follow-up study 20 years later found that all of the isolates were resistant to two or more antibiotics $[12,22]$. Other studies have reported $E$. coli isolates that are resistant to almost all available antibiotics [41 - 43].

Evidence indicates that the use of antibiotics in farm animals produced for food is linked to the emergence of resistance in bacteria pathogenic to humans (reviewed in [44]). Moreover, these animals and their wastes have become potential sources for the spread of resistant bacteria to the environment.

\section{HOW MARB REACH THE ENVIRONMENT}

As previously mentioned, antibiotic resistance occurs in nature because bacteria that live in close proximity to antibiotic-producing microorganisms have necessarily developed resistance. However, this does not explain the high levels of antibiotics and resistance that are now present in the environment. The profile of antibiotic-sensitive bacteria differs significantly from that of the pre-antibiotic era, with many more environmental samples being reported to contain bacteria resistant to antibiotics [45]. MARB in particular have increased substantially in various environments and are becoming a worldwide concern [13].

Why is this? How do MARB get into the environment? There are two ways. First, MARB can be released into the natural environment in human or animal wastes. Secondly, they can emerge and proliferate in the environment under the selective influence of man-made antibiotic substances which have been released. In either case, the presence of MARB is ultimately due to human activity, resulting in contamination of the environment with MARB, antibiotic residues, or both.

As discussed above, the digestive tracts of humans and animals that have been treated with antibiotics are significant breeding grounds for antibiotic resistant bacteria. Consequently, MARB can be present in both human and animal wastes. Animals on farms where antibiotics are used as growth promoters are probably the most important 
source of MARB in the environment. Runoff from feed-lots and from fields fertilized with manure constitutes a major source of antibiotic-resistant bacteria and leads to pollution of surface water. For example, a study of a pristine river in the Rocky Mountains [46] showed unambiguously that certain resistance genes were primarily contributed by animalfeeding operations and that they accumulated downstream of those activities.

Groundwater contamination is also a serious concern [47]. Goss et al. [48] reported that private wells on farms where manure is commonly applied are more frequently contaminated with bacteria than wells away from farms because effluents contaminated with animal feces penetrate the soil close to wells. In addition, waste from septic tanks and manure storage sites can seep into ground water or spill into surrounding watersheds [49]. It has been estimated that 10 to $34 \%$ of private wells in Canada are contaminated with bacteria [50], and even low levels of contamination are associated with increased gastrointestinal illness [51]. One study found [52] that nearly all bacteria isolated from rural groundwater supplies in West Virginia were resistant to multiple antibiotics.

In Oman, a very arid country, treated sewage effluent is often reused, for example for irrigation. One study found that this reuse of treated wastewater is a major source of groundwater pollution [53]. Approximately 300 wells were tested, as were the effluents from four major treatment plants. MARB and other contaminants detected in well water indicated sewage contamination. Ultimately, contamination from agricultural operations can reach not only groundwater and streams but also larger rivers, lakes and the ocean. Both sewage and agricultural runoff are major sources of antibiotic resistant bacteria in coastal seawater.

Resistant bacteria bred in the human digestive tract can enter the environment via sewage effluents (either treated or untreated) and sludge [12, 13, 54 - 56]. Untreated sewage is especially hazardous because of the human waste component, its capability to transmit waterborne diseases that are endemic in the community, and the large volume of waste. However, treated sewage can also be a source of antibiotic resistant bacteria in the environment [13].

Ideally, wastewater treatment removes pathogenic organisms from the water and either removes organics and solids or changes them into forms that are compatible with the environment. In many places, treated wastewater is returned to surface waters, but in arid countries it is often reused for irrigation, recharging aquifers or other purposes [15, 55, 57 59]. Unfortunately, ideal purification of water is seldom realized, so extensive recycling of wastewater greatly increases the potential for transmission of MARB [15]. Even treatment with chlorine does not completely remove bacteria from wastewater or prevent their re-growth in downstream distribution systems. For example, water taken from the Gomti River in India and used for human consumption still contained MARB, even after chlorination [17].

MARB can spread to the environment from human and animal sources, but the dissemination of antibiotic substances themselves into the environment is also a concern. Even low concentrations of antibiotic residues can give a selective advantage to resistant bacteria and lead to their emergence and proliferation in the environment. Significant amounts of drugs are released locally in waste streams from pharmaceutical plants. More broadly, compounds used in medicine and their metabolites are excreted with feces and urine into sewage. Consequently, hospital and municipal wastewater systems are major sources of antibiotics in the environment and can play an important role in the selection of antibiotic-resistant bacteria [6]. Disposal of surplus drugs into sewer systems via toilets may also be significant, though the quantities involved are unknown. Antibiotics have been clearly detected in wastewater treatment facilities [60], but they are only partially eliminated during the sewage-treatment process $[54,61,62]$. Some are subsequently released via the contaminated effluent into the aquatic environment $[14,16,18,54,63,64]$ where they can contribute to the selection of MARB in downstream distribution systems. It is probable that they are only slowly transformed by biological and physical processes [65].

Antibiotics and their metabolites can be dispersed into the environment not only in sewage but also via agricultural run-off $[12,13,15,54-56,64]$. The widespread release of disinfectants and pharmaceutical products related to agricultural and veterinary practices is thought to be a major factor in the emergence and spread of MARB [6, 56, 62]. Many antibiotics are poorly absorbed in the animal digestive tract, and it is estimated that $25 \%$ to $75 \%$ of them are excreted in feces [25]. Al-Bahry et al. [66, 67] reported that antibiotics such as tetracycline are found in chickens and find their way into the environment through urine mixed with chicken manure. Phillips et al. [7] reported that antimicrobial drugs used for animals enter the environment when manure is used as organic fertilizer. Since the annual production of waste from livestock is nearly 180 million tons in the United States alone, this is potentially a very significant source of antibiotics released into the environment. These antibiotics may end up in soil, sediment, ground water or surface water where they may exert significant selective pressure favoring resistant bacteria. The excessive use of antibiotics in aquaculture has also been reported and these drugs too can end up in the environment [5]. In Indochina, 
antibiotic residues have been found in shrimp ponds, rivers, canals and other habitats [68].

\section{ANTIBIOTICS AND MARB IN THE ENVIRONMENT AS BIOINDICATORS OF POLLUTION}

We conclude from the foregoing that MARB are increasingly common in aquatic environments and groundwater primarily due to waste streams resulting from human activity. Untreated or inadequately treated sewage and run-off from agricultural land are the most important sources. Relatively little attention has been paid to dissemination of MARB in the environment because consumption of contaminated food is considered the main route for their transmission to humans [7]. Nevertheless, resistant bacteria in the environment constitute a serious public health problem. Once established there, they can infect humans directly, or they can be acquired from meat (via re-infection of food animals), from irrigated food crops or from drinking water [67, 69 - 72], potentially resulting in infections that are difficult to treat. Even antibiotic resistance in non-pathogenic bacteria is a threat to public health because resistance can be transmitted to human pathogens [35].

Here, we are primarily interested in MARB as a sign of pollution. Antibiotics and/or MARB in the environment are symptoms of contamination and their detection is therefore diagnostic for pollution from the sources mentioned above. Tests for bacteria (not necessarily antibiotic resistant) have long been used to analyze the purity and safety of water that is used for drinking, recreation and irrigation. Analysis of coliform bacteria including E. coli is used to detect contamination by human or animal wastes and the likely presence of pathogenic bacteria of enteric origin. However, testing for antibiotic resistance (in $E$. coli or other species) can provide additional information and if resistance is detected there is even more cause for concern. To give one example, routine microbiological analyses of effluent from a wastewater treatment plant in Oman revealed levels of $E$. coli exceeding the permitted standards. Further testing showed that these $E$. coli isolates were resistant to several antibiotics commonly used to treat infections in humans [13]. This demonstrated significant potential for contamination of both groundwater and coastal water.

Dispersal of antibiotics and MARB in the environment is eventually manifested as contamination of terrestrial and marine ecosystems and the living organisms that inhabit them. Animals in the wild, especially those living in close proximity to human activities, can be exposed to antibiotic residues or bacteria with antibiotic resistance genes and can subsequently become reservoirs of MARB $[32,73]$. Antibiotic-resistant bacteria have been reported in birds, mammals, turtles, and fish, and multiple antibiotic resistances have been found in almost all species of bacteria that inhabit humans, domestic animals and wildlife [6, 14, 25, 32, 45, 54, 62].

Since MARB are relatively easily detected, this means that the presence of MARB in wildlife and environmental samples can be used as a biological indicator to detect environmental pollution and possibly monitor its degree [14 - 16, $18,54,63]$. In one application of this concept [18], MARB were isolated from soil and snails in a pond containing treated sewage effluent from industrial and residential sources. In another case, Rice et al. [45] reported high levels of resistance to aminoglycosides in environmental isolates of enterococci from aquatic habitats. Antibiotic resistant bacteria are also associated with aquaculture where one possible route for transferring the antibiotic-resistant bacteria is the release of sewage effluents into seawater. Schmidt et al. [37] demonstrated high levels of individual and multiple antimicrobial resistance within several groups of bacteria associated with aquacultural environments, including flavobacteria and aeromonads.

Marine habitats have experienced great increases in antibiotic-resistant bacteria because the coastal environment has been used as a dumping ground for sewage and other waste products. This, together with the overuse of antibiotics, agricultural runoff and coastal development, has exposed marine flora and fauna to antibiotic residues and to MARB [6, $13,14,37,62,74]$. As a result, marine organisms and the ocean environment have also become reservoirs for resistant bacteria.

In the case of ocean pollution, the use of MARB as bioindicators of pollution from contaminated effluents is a particularly attractive idea. Due to the low concentrations of pharmaceutical pollutants in seawater, they are difficult and expensive to detect using current methodologies, whereas detection of MARB is comparatively easy. In addition, surveying for the presence of pharmaceutical compounds in a large number of localities may not be feasible.

Several examples of this can be cited. Bacterial isolates from fish in Chile revealed a high incidence of MARB [75]. In Oman, antibiotic-resistant bacteria were isolated from the tissues of fish feeding near the outlet of a sewage treatment plant, strongly suggesting that infection of fish by antibiotic-resistant bacteria resulted from exposure to treated wastewater contaminating the coastal area [54].

Polluted sewage effluents are also the main source of antibiotic-resistant bacteria isolated from sea turtles, though 
agricultural runoff may also play a role. MARB have been isolated from loggerhead sea turtles (Caretta caretta) [73, 74] and high levels of antibiotic-resistant bacteria have also been found in green turtles (Chelonia mydas) [14, 63]. MARB were isolated from both turtle eggs and oviductal fluid, an indication of contaminated effluents encountered by the turtles during migration and in the feeding areas near their nesting grounds [14 - 16, 63, 74].

In summary, numerous investigations have reported the presence of MARB in sea turtles, fish, and aquatic environments. These studies indicate that pollution of coastal areas with these bacteria is widespread and should be of deep concern. They also suggest that the presence of antibiotic-resistant bacteria in marine animals such as sea turtles can be used as a bioindicator of pollution. In principle, analysis of MARB can be used to monitor the degree of pollution in the turtles' feeding grounds along the seashore and can provide an integrated assessment of the extent of contamination in the wide geographical regions where the turtles migrate.

\title{
CONCLUSION
}

Approaches to curtail the spread of multiple-antibiotic resistant bacteria in the environment are similar to the steps that are needed to deal with other forms of pollution. In general, better practices and more stringent regulations will be required to manage the usage of antibiotics and to stop the emergence and dissemination of MARB [12, 16, 18, 54]. The main strategies include using antibiotics more prudently in human and veterinary medicine, eliminating the release of untreated sewage into the environment, finding new technologies to improve wastewater treatment, and curtailing or eliminating the use of antibiotics as growth promoters in food animals.

The idea of using the presence of MARB as a bioindicator of pollution will be of great utility in implementing these strategies and monitoring their success. For example, an important part of sewage water purification in the future will be monitoring the influence of the process on the antimicrobial susceptibility profiles of bacterial indicators that could spread to the environment and to humans [33].

Phasing out the use of antibiotics as growth promoters in chickens, cattle and other food animals is well underway in Europe and has begun in the United States [9, 11, 76, 77]. This is definitely a step in the right direction because, first, using antibiotics as growth promoters breeds MARB which can potentially be very harmful to both human and animal health, and second, as resistant strains arise and are selected, the usefulness of the drugs as growth promoters will be lost. A decreased growth-promotion response to antibiotics in pigs was already noted in 1981 and was associated with the presence of bacteria having increased resistance to the agents that were used [78].

Evidence indicates that the incidence and spread of antibiotic resistance can indeed be reduced when the use of the drugs as growth promoters is stopped and the selective pressure is removed [7]. This is what one would expect [19], since when the antibiotics are not used at all, resistance is generally not observed [43, 79]. For various reasons, however, when MARB are already present, it may take a very long time for the level of resistance to decrease [80].

In Denmark, it has been possible to significantly reduce the usage of antimicrobial agents for food-animals and in general this has led to decreases in the prevalence of resistance [81]. If such approaches to curbing the spread of antibiotic resistance would be implemented internationally, the levels of MARB in sea turtles, fish and other wildlife could be used as bioindicators to monitor their success.

\section{LIST OF ABBREVIATIONS}

\author{
MARB $\quad=\quad$ Multiple-antibiotic resistant bacteria
}

\section{CONFLICT OF INTEREST}

The authors confirm that this article content has no conflict of interest.

\section{ACKNOWLEDGEMENTS}

Declared none.

\section{REFERENCES}

[1] Waksman SA. What is an antibiotic or an antibiotic substance? Mycologia 1947; 39(5): 565-9. [http://dx.doi.org/10.2307/3755196] [PMID: 20264541]

[2] Aminov RI. A brief history of the antibiotic era: lessons learned and challenges for the future. Front Microbiol 2010 ; 1 : 134. [http://dx.doi.org/10.3389/fmicb.2010.00134] [PMID: 21687759] 
[3] McManus PS, Stockwell VO. Antibiotic use for plant disease management in the United States. Plant Health Prog 2001. Available from: http://www.plantmanagementnetwork.org/pub/php/review/antibiotic/. [http://dx.doi.org/10.1094/PHP-2001-0327-01-RV]

[4] McManus PS, Stockwell VO, Sundin GW, Jones AL. Antibiotic use in plant agriculture. Annu Rev Phytopathol 2002; 40 : $443-65$. [http://dx.doi.org/10.1146/annurev.phyto.40.120301.093927] [PMID: 12147767]

[5] Cabello FC. Heavy use of prophylactic antibiotics in aquaculture: a growing problem for human and animal health and for the environment. Environ Microbiol 2006; 8(7): 1137-44. [http://dx.doi.org/10.1111/j.1462-2920.2006.01054.x] [PMID: 16817922]

[6] Kümmerer K. Antibiotics in the aquatic environment--a review--part I. Chemosphere 2009; 75(4): 417-34. [http://dx.doi.org/10.1016/j.chemosphere.2008.11.086] [PMID: 19185900]

[7] Phillips I, Casewell M, Cox T, et al. Does the use of antibiotics in food animals pose a risk to human health? A critical review of published data. J Antimicrob Chemother 2004; 53(1): 28-52. [http://dx.doi.org/10.1093/jac/dkg483] [PMID: 14657094]

[8] Carramiñana JJ, Rota C, Agustín I, Herrera A. High prevalence of multiple resistance to antibiotics in Salmonella serovars isolated from a poultry slaughterhouse in Spain. Vet Microbiol 2004; 104(1-2): 133-9. [http://dx.doi.org/10.1016/j.vetmic.2004.08.010] [PMID: 15530748]

[9] Kenny C. FDA inaction on antibiotics is making the world deadlier. Bloomberg Businessweek 2013 Dec 13; Available from: http://www.businessweek.com/articles/2013-12-23/fda-inaction-on-antibiotics-is-making-the-world-deadlier.

[10] Waterborne outbreak of gastroenteritis associated with a contaminated municipal water supply, Walkerton, Ontario, May-June 2000. Can Commun Dis Rep 2000; 26(20): 170-3. [PMID: 11211701]

[11] Antibiotic resistance threats in the United States, 2013. U.S. Department of Health and Human Services, Centers for Disease Control and Prevention 2013. Available from: www.cdc.gov/drugresistance/pdf/ar-threats-2013-508.pdf

[12] Al-Bahry SN, Elshafie AE, Al-Busaidy S, Al-Hinai J, Al-Shidi I. Antibiotic-resistant Salmonella spp. from human and non-human sources in Oman. East Mediterr Health J 2007; 13(1): 49-55. [PMID: 17546905]

[13] Al-Bahry SN, Mahmoud IY, Al-Khaifi A, Elshafie AE, Al-Harthy A. Viability of multiple antibiotic resistant bacteria in distribution lines of treated sewage effluent used for irrigation. Water Sci Technol 2009; 60(11): 2939-48. [http://dx.doi.org/10.2166/wst.2009.687] [PMID: 19934516]

[14] Al-Bahry S, Mahmoud I, Elshafie A, et al. Bacterial flora and antibiotic resistance from eggs of green turtles Chelonia mydas: an indication of polluted effluents. Mar Pollut Bull 2009; 58(5): 720-5. [http://dx.doi.org/10.1016/j.marpolbul.2008.12.018] [PMID: 19185323]

[15] Al-Bahry SN, Mahmoud IY, Al-Musharafi SK. Antibiotic resistant bacteria used as bioindicators of environmental pollution produced by tertiary treated sewage effluent. WIT Trans Ecol Environ 2012; 164: 313-21. [http://dx.doi.org/10.2495/WP120271]

[16] Al-Bahry SN, Al-Zadjali MA, Mahmoud IY, Elshafie AE. Biomonitoring marine habitats in reference to antibiotic resistant bacteria and ampicillin resistance determinants from oviductal fluid of the nesting green sea turtle, Chelonia mydas. Chemosphere 2012; 87(11): $1308-15$. [http://dx.doi.org/10.1016/j.chemosphere.2012.01.051] [PMID: 22406312]

[17] Shrivastava R, Upreti RK, Jain SR, Prasad KN, Seth PK, Chaturvedi UC. Suboptimal chlorine treatment of drinking water leads to selection of multidrug-resistant Pseudomonas aeruginosa. Ecotoxicol Environ Saf 2004; 58(2): 277-83. [http://dx.doi.org/10.1016/S0147-6513(03)00107-6] [PMID: 15157584]

[18] Mahmoud IY, Al-Bahry SN, Al-Musharafi SK. Fresh water habitat pollution by treated sewage effluent in relation to multiple-antibioticresistant bacteria. APCBEES Procedia 2013; 5: 363-7. [http://dx.doi.org/10.1016/j.apcbee.2013.05.062]

[19] Shea KM. Nontherapeutic use of antimicrobial agents in animal agriculture: implications for pediatrics. Pediatrics 2004; 114(3): 862-8. [http://dx.doi.org/10.1542/peds.2004-1233] [PMID: 15342867]

[20] Catry B, Laevens H, Devriese LA, Opsomer G, De Kruif A. Antimicrobial resistance in livestock. J Vet Pharmacol Ther 2003; $26(2)$ : 81-93. [http://dx.doi.org/10.1046/j.1365-2885.2003.00463.x] [PMID: 12667177]

[21] Guidelines for drinking-water quality. Vol. III: Surveillance and Control of Community Supplies. Eastern Mediterranean Regional Office, Regional Center for Environmental Health Activities (CEHA), Amman, Jordan 1997.

[22] Al-Bahry S. Antibiotic resistance of Salmonella isolated from Muscat. Pakistan J Biol Sci 1999; 2: 523-8.

[23] Jeljaszewicz J, Mlynarczyk G, Mlynarczyk A. Antibiotic resistance in Gram-positive cocci. Int J Antimicrob Agents 2000; 16(4): 473-8. [http://dx.doi.org/10.1016/S0924-8579(00)00289-2] [PMID: 11118861]

[24] Al-Ghamdi M, El-Morsy F, Al-Mustafa ZH, Faiz M, Al-Ramadhan M. Bacterial organisms isolated from healthy chickens in the Entran province of Saudi Arabia and their pattern of resistance to antimicrobial agents. Sci J King Faisal Univ 2001; 2: 113-28. 
[25] Chee-Sanford JC, Aminov RI, Krapac IJ, Garrigues-Jeanjean N, Mackie RI. Occurrence and diversity of tetracycline resistance genes in lagoons and groundwater underlying two swine production facilities. Appl Environ Microbiol 2001; 67(4): $1494-502$. [http://dx.doi.org/10.1128/AEM.67.4.1494-1502.2001] [PMID: 11282596]

[26] van den Bogaard AE, London N, Driessen C, Stobberingh EE. Antibiotic resistance of faecal Escherichia coli in poultry, poultry farmers and poultry slaughterers. J Antimicrob Chemother 2001; 47(6): 763-71. [http://dx.doi.org/10.1093/jac/47.6.763] [PMID: 11389108]

[27] Ash RJ, Mauck B, Morgan M. Antibiotic resistance of gram-negative bacteria in rivers, United States. Emerg Infect Dis 2002; 8(7): 713-6. [http://dx.doi.org/10.3201/eid0807.010264] [PMID: 12095440]

[28] Davison J. Genetic exchange between bacteria in the environment. Plasmid 1999; 42(2): 73-91. [http://dx.doi.org/10.1006/plas.1999.1421] [PMID: 10489325]

[29] Normark BH, Normark S. Evolution and spread of antibiotic resistance. J Intern Med 2002; 252(2): $91-106$. [http://dx.doi.org/10.1046/j.1365-2796.2002.01026.x] [PMID: 12190884]

[30] Kobashi Y, Hasebe A, Nishio M, Uchiyama H. Diversity of tetracycline resistance genes in bacteria isolated from various agricultural environments. Microbes Environ 2007; 22: 44-51. [http://dx.doi.org/10.1264/jsme2.22.44]

[31] Kümmerer K. Resistance in the environment. J Antimicrob Chemother 2004; 54(2): 311-20. [http://dx.doi.org/10.1093/jac/dkh325] [PMID: 15215223]

[32] Allen HK, Donato J, Wang HH, Cloud-Hansen KA, Davies J, Handelsman J. Call of the wild: antibiotic resistance genes in natural environments. Nat Rev Microbiol 2010; 8(4): 251-9. [http://dx.doi.org/10.1038/nrmicro2312] [PMID: 20190823]

[33] Rahman M, Huys G, Kühn I, Rahman M, Möllby R. Prevalence and transmission of antimicrobial resistance among Aeromonas populations from a duckweed aquaculture based hospital sewage water recycling system in Bangladesh. Antonie van Leeuwenhoek 2009; 96(3): 313-21. [http://dx.doi.org/10.1007/s10482-009-9348-1] [PMID: 19459063]

[34] Hardy K. Bacterial Plasmids. In: Cole JA, Knowles CJ, Schlessinger D, Eds. Aspects of Microbiology, volume 4. Washington D. C.: American Society of Microbiology 1981.

[35] Van der Kooij D, Van Lieverloo JH, Schellart J, Hiemstra P. Maintaining quality without a disinfectant residual. J Am Water Works Assoc 1999; 91: 55-64.

[36] Koonin EV, Makarova KS, Aravind L. Horizontal gene transfer in prokaryotes: quantification and classification. Annu Rev Microbiol 2001; 55: 709-42.

[http://dx.doi.org/10.1146/annurev.micro.55.1.709] [PMID: 11544372]

[37] Schmidt AS, Bruun MS, Dalsgaard I, Pedersen K, Larsen JL. Occurrence of antimicrobial resistance in fish-pathogenic and environmental bacteria associated with four danish rainbow trout farms. Appl Environ Microbiol 2000; 66(11): 4908-15. [http://dx.doi.org/10.1128/AEM.66.11.4908-4915.2000] [PMID: 11055942]

[38] Mirza S, Kariuki S, Mamun KZ, Beeching NJ, Hart CA. Analysis of plasmid and chromosomal DNA of multidrug-resistant Salmonella enterica serovar typhi from Asia. J Clin Microbiol 2000; 38(4): 1449-52. [PMID: 10747124]

[39] Al-Bahry SN, Al-Mashani BM, Al-Ansari AS, Elshafie AE, Mahmoud IY. Escherichia coli tetracycline efflux determinants in relation to tetracycline residues in chicken. Asian Pac J Trop Med 2013; 6(9): 718-22. [http://dx.doi.org/10.1016/S1995-7645(13)60125-X] [PMID: 23827150]

[40] Percival S, Chalmers R, Embrey M, Hunter P, Sellwood J, Wyn-Jones P. Microbiology of waterborne diseases. Boston: Elsevier Academic Press 2004.

[41] Reinthaler FF, Posch J, Feierl G, et al. Antibiotic resistance of E. coli in sewage and sludge. Water Res 2003; 37(8): 1685-90. [http://dx.doi.org/10.1016/S0043-1354(02)00569-9] [PMID: 12697213]

[42] Tabatabaei RR, Nasirian A. Isolation, identification and antimicrobial resistance patterns of E. coli isolated from chicken flocks. Iranian J Pharmacol Therap 2003; 2: 39-42.

[43] Miles TD, McLaughlin W, Brown PD. Antimicrobial resistance of Escherichia coli isolates from broiler chickens and humans. BMC Vet Res 2006; $2: 7$.

[http://dx.doi.org/10.1186/1746-6148-2-7] [PMID: 16460561]

[44] Mølbak K. Spread of resistant bacteria and resistance genes from animals to humans--the public health consequences. J Vet Med B Infect Dis Vet Public Health 2004; 51(8-9): 364-9. [http://dx.doi.org/10.1111/j.1439-0450.2004.00788.x] [PMID: 15525367]

[45] Rice EW, Messer JW, Johnson CH, Reasoner DJ. Occurrence of high-level aminoglycoside resistance in environmental isolates of enterococci. Appl Environ Microbiol 1995; 61(1): 374-6. [PMID: 7887619]

[46] Pruden A, Arabi M, Storteboom HN. Correlation between upstream human activities and riverine antibiotic resistance genes. Environ Sci Technol 2012; 46(21): 11541-9. 
[http://dx.doi.org/10.1021/es302657r] [PMID: 23035771]

[47] Leclerc H, Schwartzbrod L, Dei-Cas E. Microbial agents associated with waterborne diseases. Crit Rev Microbiol 2002; 28(4): 371-409. [http://dx.doi.org/10.1080/1040-840291046768] [PMID: 12546197]

[48] Goss MJ, Barry DA, Rudolph DL. Contamination in Ontario farmstead domestic wells and its association with agriculture: 1. Results from drinking water wells. J Contam Hydrol 1998; 32: 267-93. [http://dx.doi.org/10.1016/S0169-7722(98)00054-0]

[49] McEwen SA, Fedorka-Cray PJ. Antimicrobial use and resistance in animals. Clin Infect Dis 2002; 34(Suppl. 3): S93-106. [http://dx.doi.org/10.1086/340246] [PMID: 11988879]

[50] Salvadori M, Coleman BL, Louie M, McEwen S, McGeer A. Consumption of antimicrobial-resistant Escherichia coli contaminated well water: Human health impact. PSI Clin Res 2004; 1: 6-25.

[51] Cabelli VJ, Dufour AP, McCabe LJ, Levin MA. Swimming-associated gastroenteritis and water quality. Am J Epidemiol 1982; 115(4): 606-16. [PMID: 7072706]

[52] McKeon DM, Calabrese JP, Bissonnette GK. Antibiotic resistant gram-negative bacteria in rural groundwater supplies. Water Res 1995; 29: 1902-8

[http://dx.doi.org/10.1016/0043-1354(95)00013-B]

[53] Al-Bahry SN, Mahmoud IY, Al-Belushi KIA, Elshafie AE, Al-Harthy A, Bahkeit CK. Al-Gharibi IS, Al-Harthy A, Al-Zadjali HA. Microbial and chemical pollution of water-wells relative to sewage effluents in Oman. IAFOR J Sustain Energy Environ 2014; 1: 35-56.

[54] Al-Bahry SN, Mahmoud IY, Al-Belushi KI, Elshafie AE, Al-Harthy A, Bakheit CK. Coastal sewage discharge and its impact on fish with reference to antibiotic resistant enteric bacteria and enteric pathogens as bio-indicators of pollution. Chemosphere 2009; 77(11): 1534-9. [http://dx.doi.org/10.1016/j.chemosphere.2009.09.052] [PMID: 19853276]

[55] Al-Bahry SN, Mahmoud IY, Al-Musharafi SK. The effect of physical factors on fecal coliform viability rate in sewage sludge. J Geosci Environ Prot 2014; 2: 9-13.

[56] Guardabassi L, Petersen A, Olsen JE, Dalsgaard A. Antibiotic resistance in Acinetobacter spp. isolated from sewers receiving waste effluent from a hospital and a pharmaceutical plant. Appl Environ Microbiol 1998; 64(9): 3499-502. [PMID: 9726904]

[57] Al-Musharafi SK, Mahmoud IY, Al-Bahry SN. Heavy metal contamination from treated sewage effluents. WIT Trans Ecol Environ 2012; 164: 381-9.

[58] Al-Musharafi SK, Mahmoud IY, Al-Bahry SN. Heavy metal pollution from treated sewage effluent. APCBEES Procedia 2013; 5: 344-8. [http://dx.doi.org/10.1016/j.apcbee.2013.05.059]

[59] Al-Musharafi SK, Mahmoud IY, Al-Bahry SN. Environmental contamination by industrial effluents and sludge relative to heavy metals. J Geosci Environ Prot 2014; 2: 14-8.

[60] Karthikeyan KG, Meyer MT. Occurrence of antibiotics in wastewater treatment facilities in Wisconsin, USA. Sci Total Environ 2006; 361(1-3): 196-207. [http://dx.doi.org/10.1016/j.scitotenv.2005.06.030] [PMID: 16091289]

[61] Watkinson AJ, Murby EJ, Costanzo SD. Removal of antibiotics in conventional and advanced wastewater treatment: implications for environmental discharge and wastewater recycling. Water Res 2007; 41(18): 4164-76. [http://dx.doi.org/10.1016/j.watres.2007.04.005] [PMID: 17524445]

[62] Kümmerer K. Antibiotics in the aquatic environment--a review--part II. Chemosphere 2009; 75(4): $435-41$. [http://dx.doi.org/10.1016/j.chemosphere.2008.12.006] [PMID: 19178931]

[63] Al-Bahry SN, Mahmoud IY, Al-Zadjali M, Elshafie A, Al-Harthy A, Al-Alawi W. Antibiotic resistant bacteria as bio-indicator of polluted effluent in the green turtles, Chelonia mydas in Oman. Mar Environ Res 2011; 71(2): 139-44. [http://dx.doi.org/10.1016/j.marenvres.2010.12.005] [PMID: 21237506]

[64] Weigel S. Occurrence, distribution and fate of pharmaceuticals and further polar contaminants in the marine environment. PhD Dissertation. Hamburg: University of Hamburg 2003. www.chemie.uni-hamburg.de/bibliothek/2003/DissertationWeigel.pdf

[65] Fono LJ, Kolodziej EP, Sedlak DL. Attenuation of wastewater-derived contaminants in an effluent-dominated river. Environ Sci Technol 2006; 40(23): 7257-62. [http://dx.doi.org/10.1021/es061308e] [PMID: 17180975]

[66] Al-Bahry SN, Mahmoud IY, Al-Musharafi SK. The overuse of tetracycline compounds in chickens and its impact on human health. IPCBEE 2013; 50: 21-5.

[67] Al-Bahry SN, Al-Hinai JA, Mahmoud IY, Al-Musharafi SK. Opportunistic and microbial pathogens in municipal water distribution systems. APCBEES Procedia 2013; 5: 339-43. [http://dx.doi.org/10.1016/j.apcbee.2013.05.058]

[68] Suzuki S, Hoa PT. Distribution of quinolines, sulfonamides, tetracyclines in the aquatic environment and antibiotic resistance in Indochina. Front Microbiol 2012; 3: 1-8. [http://dx.doi.org/10.3389/fmicb.2012.00067] [PMID: 22275914] 
[69] Al-Bahry SN, Elshafie AE, Victor R, Mahmoud IY, Al-Hinai JA. Opportunistic pathogens relative to physicochemical factors in water storage tanks. J Water Health 2011; 9(2): 382-93. [http://dx.doi.org/10.2166/wh.2011.054] [PMID: 21942202]

[70] Linton AH, Howe K, Bennett PM, Richmond MH, Whiteside EJ. The colonization of the human gut by antibiotic resistant Escherichia coli from chickens. J Appl Bacteriol 1977; 43(3): 465-9. [http://dx.doi.org/10.1111/j.1365-2672.1977.tb00773.x] [PMID: 342480]

[71] Myaing TT, Saleha AA, Arifah AK, Raha AR. Antibiotic resistance and plasmid carriage among Escherichia coli isolates from chicken meat in Malaysia. In: Makkar HPS, Viljoen Gj, Eds. Applications of gene-based technologies for improving animal production and health in developing countries. Amsterdam NL: Springer 2005; pp. 521-7. [http://dx.doi.org/10.1007/1-4020-3312-5_37]

[72] Painter JA, Hoekstra RM, Ayers T, et al. Attribution of foodborne illnesses, hospitalizations, and deaths to food commodities by using outbreak data, United States, 1998-2008. Emerg Infect Dis 2013; 19(3): 407-15. [http://dx.doi.org/10.3201/eid1903.111866] [PMID: 23622497]

[73] Harms CA, Mihnovets AN, Braun-McNeill J, et al. Cloacal bacterial isolates and antimicrobial resistance patterns in juvenile loggerhead turtles in North Carolina, USA. Proceedings of the 26th International Symposium on Sea Turtle Biology and Conservation. April 3-8, 2006; Crete, Greece. 2006; p. 58.

[74] Foti M, Giacopello C, Bottari T, Fisichella V, Rinaldo D, Mammina C. Antibiotic Resistance of Gram Negatives isolates from loggerhead sea turtles (Caretta caretta) in the central Mediterranean Sea. Mar Pollut Bull 2009; 58(9): 1363-6. [http://dx.doi.org/10.1016/j.marpolbul.2009.04.020] [PMID: 19473669]

[75] Miranda CD, Zemelman R. Antibiotic resistant bacteria in fish from the Concepción Bay, Chile. Mar Pollut Bull 2001; $42(11)$ : 1096-102. [http://dx.doi.org/10.1016/S0025-326X(01)00093-5] [PMID: 11763221]

[76] Marshall BM, Levy SB. Antibiotics in the animals we eat. The Scientist 2012 (April) Available from: http://www.the-scientist.com/ ?articles.view/ articleNo/31895/title/Antibiotics-in-the-Animals-We-Eat/

[77] FDA. Guidance for Industry \#213. New animal drugs and new animal drug combination products administered in or on medicated feed or drinking water of food producing animals. Recommendations for drug sponsors for voluntarily aligning product use conditions with GFI \#20. U.S. Department of Health and Human Services, Food and Drug Administration, Center for Veterinary Medicine 2013.

[78] Hayes VW. In Jolly DW, Ed. Antibiotic usage -The situation in the United States then and now. Ten years on from Swann, Association of Veterinarians in Industry 1981.

[79] Hart WS, Heuzenroeder MW, Barton MD. Antimicrobial resistance in Campylobacter spp., Escherichia coli and enterococci associated with pigs in Australia. J Vet Med B Infect Dis Vet Public Health 2004; 51(5): 216-21. [http://dx.doi.org/10.1111/j.1439-0450.2004.00760.x] [PMID: 15330980]

[80] Spratt BG. Antibiotic resistance: counting the cost. Curr Biol 1996; 6(10): 1219-21. [http://dx.doi.org/10.1016/S0960-9822(96)00700-2] [PMID: 8939559]

[81] Aarestrup FM. Veterinary drug usage and antimicrobial resistance in bacteria of animal origin. Basic Clin Pharmacol Toxicol 2005; 96(4): $271-81$.

[http://dx.doi.org/10.1111/j.1742-7843.2005.pto960401.x] [PMID: 15755309]

(C) Paulson et al.; Licensee Bentham Open

This is an open access article licensed under the terms of the Creative Commons Attribution-Non-Commercial 4.0 International Public License (CC BY-NC 4.0) (https://creativecommons.org/licenses/by-nc/4.0/legalcode), which permits unrestricted, non-commercial use, distribution and reproduction in any medium, provided the work is properly cited. 